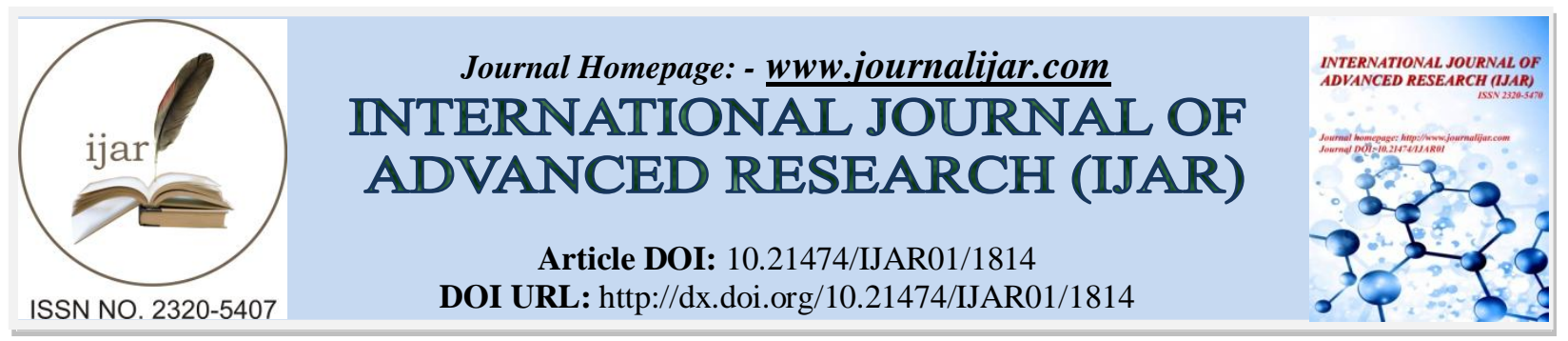

RESEARCH ARTICLE

\title{
EFFECT OF SHIROVASTHI AND NASYAM IN CEREBELLAR DISORDER.
}

Dr. Sreeja. A ${ }^{1}$, Dr. Praveenkumar ${ }^{2}$ and Dr. Ch. Sadanandam ${ }^{3}$.

1. M.D Final Year, PG Dept. Of Panchakarma, Dr.B.R.K.R.Govt. Ayurvedic Medical College, Erragadda, Hyderabad, T.G.

2. Lecturer,Dept of Panchakarma, Dr. B.R.K.R.GovtAyurvedic Medical College, Erragadda, Hyderabad, T.G.

3. H.O.D PG.Dept of Panchakarma, Dr. B.R.K.R.GovtAyurvedic Medical College, Erragadda, Hyderabad, T.G.

\section{Manuscript Info}

\section{Manuscript History}

Received: 12 August 2016

Final Accepted: 22 September 2016

Published: October 2016

Key words:-

Ayurveda,cerebellarataxia,shirovasthi, nasyam,balance

\section{Abstract}

Purpose:- The purpose of this paper is to know the effect of Ayurvedic therapies like Shirovasthi and Nasyam in cerebellar ataxia.

Design/methodology/Approach:- We conducted single case study on 45yrs old male patient with diagnosed progressive Cerebellar Ataxia.Treatment consisted of Shirovasthi [therapeutic retention of oil over the scalp]with Brahmi taila[medicated oil]for 20 minutes for 14 days followed by Pratimarsha nasyam with Anu tailam.

Results:- Reported subjective improvement in walking, there was significant improvement in overall and anterio posterior balance, speech and power.

Conclusion:- Over a short period of the present study with Ayurvedic therapies (Shirovasthi and PratimarshaNasyam) were found to be safe and showed improvement in balance in patient with progressive Cerebellar Disorder. further studies are needed to prove its efficacy and validate the results.

Copy Right, IJAR, 2016,. All rights reserved.

\section{Introduction:-}

Progressive Cerebellar ataxia is a medical condition involving a degenerative process of the central nervous system which results in a progressive loss of coordination of gait, limb movement, as well as vision, swallowing, and cognition. Genetic causes as well as diseases like multiple sclerosis and alcohol intake may be cause. Cerebellar disease is believed to be responsible for progressive Cerebellar ataxia. Currently there is no specific modern management for this condition. Treatment of symptoms is therefore more important as well as offering supportive care, preventing complications, halting further progression is important. Ayurvedic therapies (Shirovasthi and Nasyam)for progressive Cerebellar ataxia is aimed at halting the degenerative process of the central nervous system as well as strengthening the nervous system so as to improve the functioning of the nerve cells and the chemical neurotransmitters connecting the nerve synapses. These Ayurvedic procedures have a known and specific action on brain cells as well as nerve cells, the affected individual gradually starts noticing improvement in neuromuscular coordination and bodily functions.

\section{Case report:-}

A male patient of $45 \mathrm{yrs}$ old presented with complaint of unable to walk steadily, slowness in movement, patient noticed imbalance and incoordination involving gait and limbs there was gradually declining balance and slightly 
slurred speech. The symptoms developed within six months and had slow progression. There was no similar family history [to rule out genetic cause] no history of trauma, any other chronic illness, patient was known alcoholic.

\section{Clinical Examination:-}

Dashvidha Pariksha: Prakriti:- VataPittaja Vikriti : Vataja (pravara)Sara: Madhyama Samhana : Madhyama Ahara Shakti Abhyarana Shakti :avara Jarana Shakti : Avara Vyayam Shakti : Avara Vaya : Madhyama Satva : Madhyama Satmya: Madhyama Bala : Avara

General Physical Examination:- B.P. $=140 / 90 \mathrm{mmHg}, \quad$ P/R $=64 / \mathrm{min}, \quad$ Pallor--ve, Icterus-ve, Cyanosis-ve, Clubbing-ve, Oedema-ve. CVS: S1 S2 Normal .Chest: B/L equal air entry with no added sound CNS: Higher function normal

\section{Reflexes}

Upper limb: Slightly exaggerated

Lower limb: Moderately exaggerated

knee Jerk 3+ (B/L) Ankle Jerk: 2+

Plantar response: extensor. Muscle Power/strength: 3/5 in both lower limbs, sensory - intact. Muscular Atrophy: absent

\section{Assessment of movement and coordination -before therapy:-}

Following tests were done to assess the effect of therapy on movement and coordination Heel to shin test, Finger nose test, Rapid alternating finger movements, Rapid alternating hand movements. Patient was asked to produce 2 or more words simultaneously --- like April-may, Ding-dong ,Nystagmus - Oscillatory movements of eye ball.

\section{Investigation:-}

All routine investigations were found normal. In MRI there were degenerative changes in cerebellum.

\section{Treatment plan:-}

According to Ayurveda Cerebellar disorder being neurological disorder can be correlated with Vatavyadhi. Therefore management was planned to alleviate the Vata. Here it is important to mention that Vata is vitiated due to dhatukshaya as well as due to avarana.

\section{Materials and methods:-}

We conducted Shirovasthi with Brahmitaila for 2 weeks and simultaneously Pratimarsha Nasyam with Anutaila 2 drops in each nostril for 3 weeks .

Shirovasti procedure: Patient was made to sit in erect on a chair one strip of cloth smeared with masha kalka is pasted around head, above the ears .then leather sheet of about 12 angulas ,applied with masha kalka at the bottom of inner surface of it is tied around the head, so that lower part of the leather sheet is attached to the strip of cloth .then tie another strip of cloth pasted with masha kalka joining two ends of leather sheet .Now vasthi yantra is ready Then the Brahmitaila was poured in inner surface of leather cap .The level of oil kept 2 angula above scalp Temperature of Snehadravya was "Sukhoshna"

\section{Shirovasti Dharankala:-}

The references available in various texts regarding Shirovasti Dharanakala are as follows:

a. According to Lakshana;TheSneha should be removed when the watery discharge from ear, mouth and nose appears.

b. According to VyadhiAvastha;TheSneha should be retained on the head till the disorder is relieved or till the pain of head subsides.

c. According to Kala; The duration of retention of to Shirovasthi varies according to kala, as given below -Vata disorders 10,000 matras Pitta or Rakta disorders 8,000 matras Kapha disorders 6,000 matras Swastha person 1,000 matras Here in this case we are doing for 20 minutes 


\section{Drugs to be used in Shirobasti therapy:-}

In the present case Brahmi Taila was used for Shirovasthi,Brahmi being best Medhya dravya benefits entire Nervous system by nourishing and calming the nerves, reduces stress and over stimulation.

\section{Nasyam:-}

Nasya karma is the most important therapy as it is used for the treatment of Urdhva jatrugata diseases.According to Charaka nose is the gate way of head. The drug administered through nose as Nasya reaches the brain and eliminates vitiated doshas Producing the disease ,We administered Pratimarsha Nasyam[2-3drops in each nostril] with Anutailam .

Pratimarsha nasya: it could be given daily and even in all seasons,Pratimarsha Nasya with Anutaila was even indicated as a regimen in swasthavritta.As it is given in little quantity it acts as Brhumhana rather than shodhana.

\section{Administration of Nasya:-}

The patient was laid down in supine position in head lowered position and foot part is to be slightly raised. After covering the eyes with clean cotton cloth, the tip of the patient's nose was raised with the left thumb and with the right hand the luke warm (Sukhoshna drug)Anutaila was dropped in both the nostrils 2 drops in each nostril. Paschat Karma: After administration of medication through nasal passage patient should lie in supine (Uttana) position for about 2 minute or for counting numbers up to 100. After an administration of Nasya feets, shoulders, palms and ears should be massaged. The head, cheek and neck should be again subjected to sudation .

\section{Treatment duration:-}

Pratimarsha Nasya for 3 weeks Shirovasthi for 2 weeks simultaneously

\section{Results:-}

Before treatment After treatment

\begin{tabular}{|l|l|}
\hline $\begin{array}{l}\text { Patient was unable to walk on straight line with eyes } \\
\text { closed }\end{array}$ & $\begin{array}{l}\text { Patient was unable to walk eyes closed but could stand } \\
\text { by keeping feet together }\end{array}$ \\
\hline Finger nose test $+\mathrm{ve}$ & Finger nose test - ve \\
\hline Muscle power $3 / 5$ & Muscle power4/5 \\
\hline Deep tendon reflexes slightly exaggerated & No change in Deep tendon reflexes \\
\hline Tremors were present & No improvement \\
\hline Speech;pt could not produce 2 words simultaneously & Pt able to talk two words simultaneously \\
\hline
\end{tabular}

\section{Discussion:-}

Cerebellar ataxia can occur as a result of many diseases and presents with symptoms of inability to coordinate balance, gait,extremity and eye movements. There are many causes of cerebellar ataxia including direct injury,alcohol use and genetic cause.Misfunction of sodium -pottasium pump may be factor in some cerebellar atxais In cerebellar ataxiashirovasthi and pratimarsha are found to be better option Role of Sirovasti Shirobasti has been reported to be having an excellent result on such disorders as it gives strength to the central nervous system. It calmsdown both the mind and the senses which allow the body's natural healing mechanism to release stress from the nervous system by pacifying Vatadosha, particularly Pranavayu. The procedure of sirovasti imparts benefits of both snehana and swedana simultaneously.

The temperature of the taila in Shirovasti, leads to peripheral vasodilatation. This increases the peripheral circulation which nourishes the tissues, hastens phagocytosis and brings about regenerative changes. The neurotransmitters released during this period improve the afferent and efferent pathways and eventually the tonicity of muscles affected get improved.

As the nervous system is mainly composed of lipoid tissue, the taila being lipid in nature is quickly absorbed due to the rich vasculature of the scalp and gets distributed to different parts of the brain through the communicating veins. It could relax the tight junctions between endothelial cells in the CNS vessels and facilitate the entry of solutes and other components into the CNS

.Role of Nasyam: According to Charaka nose is the gate way of head. The drug administered through nose as Nasya reaches the brain and eliminates morbid dosha producing the disease. In Astanga Samgraha it is explained that nose being the entry to Shiras (head) the drug administered through nose as Nasya reaches shringataka a siramarma by 
nasa srotas and spreads in the murdha (brain)reaches at a junction place of netra(eye) kanta(throat) detach the morbid doshas present above jatru and expel from uttamanga. In Ayurvedic texts Pratimarsha nasya is indicated as daily regimen to maintain health .Cerebellar ataxia being degenerative disorder in Ayurvedic context it can be taken as dhatukshayaja vikruthi i.e., apatarpanajanyavyadhi hence treatment include santarpanachikitsa., here as Pratimarshanasya given (lesser dose 2 drops)it acts better as santarpana rather than shodana(expelling the doshas).

\section{Conclusion:-}

In the above case presenting with degenerative Cerebellar Ataxia,ayurvedic therapeutic procedures Shirovasthi and Pratimarsha nasyam were found to be effective in improving balance in walking, improvement of speech and power . However further studies are needed to validate the results and to know the mode of action of these procedures of these procedures and there efficacy. Currently there is no specific management for this condition in modern medicine, hence further study must be conducted to treat this condition with Ayurveda.

\section{References:-}

1. Charaksamhita by Agnivesh, YadavjiTrikramjiAcharya, ChaukhambhaPrakashan, Varanasi, reprint 2009.

2. Carakasamhita with ayurvedicdeepika commentary by chakrapaniduttachowkambha Krishna das academy $2^{\text {nd }}$ edition.varanasi sutra stana 20

3. Ashtangahrudaya sutra stana with commentaries sarvangasundara of Arunadutta.chaukambhaoreintaliaVaranasi sutra stana $22 / 26$ to 29,30

4. Sushrutasamhithachikitsastana $40^{\text {th }}$ chapter 22,23 slokas translated by R.K Sharma

5. Sushruthasamhithachikitsastana $2^{\text {nd }}$ chapter $40 / K$.R.Srikantamurthytranslation chaukambhaorientaliaAnsari OA, Gambhir IS\&Tripathi JS-

6. Comparative clinical Evaluation of SaraswatGhrit and Shirobasti in the management of Senile Dementia, MD (Ay.) thesis, IMS, BHU, Varanasi, 2012.

7. Carakasamhithasiddistana $9^{\text {th }}$ chapter translated by R.K.Sharmachaukambha Sanskrit series.

8. Hutchinsons clinical methods nuerological examination 